\title{
WHEN WILL POWDER TECHNOLOGY MAKE ITS PRESENCE FELT IN THAILAND?
}

\author{
Wiwut TANTHAPANICHAKOON*
}

\begin{abstract}
要 約
タイ国では，さまざまな粉体関連機器が，農業，工業などの幅広い分野で使用されているものの，学問として の粉体工学は，ほとんどない状態であり，核となる研究者や企業あほとんどいないのが現状である。これは，タ イ国の工学全体が未分化であり, 鉱山学以外では独立した学会組織を持っていないととに因るとてろが大である。 したがって，粉体工学のように非常に専門化した分野ではなおさらである。

てのため, タイ国には先進国の技術や知識の導入を計る団体が多数あるが，なかでむ，泰日経済技術振興会 ( T P A ) は先進的な役割を果している。TPAは日本の経済援助により，日本への留学経験を持つ人達を中心に 組織された非営利団体であり, セミナー, 翻訳出版, 日本語教育等に精力的に取り組んでいる。粉体工学との関連 では, これまでに, 大気污染と集塵技術に関するセミナーを開いた程度であまり活発とはいえない。しかし，今後 は固体ハンドリングや空気輸送について，セミナー，翻訳を手掛けたいと考えている。

いづれにしても, タイ国に粉体工学が定着するかどうかは工業化のスピード, それをとりまく環境の変化など にむよるが, 最む重要なととはタイ国内に核となる研究者グループが形成されることであろう。このためには外 国からの援助が必要であり，その空口として，Chulalongkorn大学や，T P A が一定の役割を果せると思う。
\end{abstract}

\section{Present Status of Powder Technology in Thai- land}

As a tool, powder technology has long been put to many good uses in various industries of Thailand. In the agricultural sector, the vibratory screen is a common fixture to every rice mill, feed mill, maize silo, etc. The pelletizer is found in animal feed plants, fertilizer plants, and so on. Belt conveyors are also widely used in any factory that handles solid materials of diverse shapes. In the industrial sector, penumatic conveyors are used in flour mills, cement plants, and so forth. Comminution

昭和 60 年 8 月 1 日受付
* Department of Chemical Engineering,
Chulalongkorn University, Bangkok,
Thailand 10500

〈著者紹介〉

1949 年 12 月 1 日生

1973 年 3 月京都大学工学部化学工学科卒

1978 年米国 Texas 大学, Dept. Chem. Eng. Ph. D 取得

現在 タイ国 Chulalongkorn 大学工学部化学工学科Assoc. Professor is another operation used extensively in mining, cement plants, flour mills, etc. Currently, in addition to cyclones and bag filters, a number of large plants, including power generating plants and cement plants have taken to the installation of electrostatic precipitators in order to satisfy the emission standard. In the construction industry, screens and mixers are indispensable to the preparation of concrete. In fact, the more one thinks about it, the more examples one will find of powder technology at work in Tahiland as well as in any parts of the world.

As a discipline, however, powder technology is still in its infancy in Thailand. By discipline, the author means the treatment of powder technology in a scientific and systematic manner. This does not imply that empiricism and practical experiences are to be banished. On the contrary, they are necessary to the induction of new laws and confirmation of bold theories. What is missing in Thailand is not the lack of interest in the discipline of powder technology but a small group of academicians and industrial practitioners that will serve as a core to publicize, promote and spearhead powder technology and its applications here. 


\section{Thai Academic Institutions and Powder Tech- nology}

The number of universities in Thailand used to be around 12 until a couple of private ones were permitted to open a few years back. Of these, Chulalongkorn University (CU) is the oldest and most comprehensive, lacking only agriculture. The second oldest is Thammasart University, which has a high reputation in law, public administration and business administration, and is planning to set up engineering in the near future. Kasetsart University used to be the only institution that offered agriculture (in fact, its name means agriculture in Thai), but it now also teaches engineering. Some universities, such as the King Mongkut Institute of Technology (KMIT), are the outgrowth of technical and vocational colleges in the past two decades and have mainly engineering, science, and agriculture. Most universities are located in the Bangkok Metropolitan Area. The few large ones in the countryside are Chiengmai University in the north, Prince of Songkla University (PSU) in the south and Khonkhan University (KKU) in the northeast.

Only CU, KMIT and PSU currently have chemical engineering, and KKU will soon open one. Because Thailand has a relatively small chemical process industry her chemical engineering is only about twenty-five years old and it only became a separate division of the Engineering Institute of Thailand about 5 years ago. Thus unlike Japan, where powder technology not only has its own society and association, but her other societies such as Society of Chemical Engineers and Society of Mechanical Engineers, also play key roles in the advancement of powder technology, powder technology may be likened to an infant without parents in Thailand.

The other engineering branches that usually deal with certain aspects of powder technology are mining, mechanical engineering, material transport technology, agricultural engineering, and environmental engineering. However, the emphasis or interest is not powder technology per se (i.e. not as a discipline), but rather operations and equipment that deal with the handling and processing of solids. Unfortunately, there is still no distinct group of researchers with special interest in powder technology here.

\section{Thai Professional Organizations and Powder Technology}

The largest professional organization in engineering here is the Engineering Institute of Thailand (EIT) with an active membership of about 8,000 out of a total of around 20,000 . The Institute currently has five divisions: civil engineering, electrical engineering, mechanical engineering, industrial engineering, and chemical engineering. Only mining engineering has a its own separate association, though the emphasis of that association is not limited to the promotion of mining technology.

Because EIT is a very large professional organization with diverse interest, some recent engineering graduates, for one reason or another, fail to identify with the institute and are quite reluctant to join. Eventually some day will come when EIT would probably grow too big and unwieldly, and choose to break up into various smaller professional societies. Meanwhile, either its mechanical engineering division or chemical engineering division is in a position to promote powder technology, if it can be convinced to do so.

\section{Non-Profit Technical Associations and Pow- der Technology}

There are numerous technical associations registered in Thailand, but most of them are small in size and quite specific in technical areas of interest. Some even act more like a trade organization than promoter of technical knowledge. Currently the most active and purely technical non-profit association in Thailand is the Technological Promotion Association (Thai-Japan). Since the association (TPA) has been very successful in the introduction and transfer of new technology from abroad, the author wishes to take the opportunity to introduce TPA and to elaborate its potential role vis-a-vis powder technology.

\section{Technological Promotion Association (Thai- Japan)}

TPA was established as a non-profit association in January 1973 by an organizing committee headed by H.E. Sommai Hoontrakul, currently Minister of Finance, with the objectives of promoting and supporting technological advancement for its members and the general public. The establishment was accomplished with the cooperation and selfless dedication of the alumni and former recipients of ABK (Asia Bunka Kaikan) and AOTS (Association for Overseas Technical Scholarship) scholarships to Japan. Another important source of cooperation and assistance came from Mr. Goichi Hozumi, past Chief Director of ABK, AOTS, and JTECS (Japan-Thailand Economic Cooperation Society).

Since its rather unique inception, TPA has been receiving 
financial assistance for its activities in technological promotion and transfer from Japan, mainly the Ministry of international Trade and Industry and JTECS. As of July 1985, TPA has 531 members, 1,147 associate members and 226 corporate members, all of whom pay either a small annual fee according to the type of membership of a lifelong fee. The fees, however, represent just a fraction of the benefits that a typical member receives from TPA.

The association is under the sole administration of an entirely Thai Board of Executive Directors and the office is run by a dedicated and efficient staff, mostly Thai personnel. The main activities of TPA may be categorized into seven types of projects, each administered by a subcommittee along the general guideline laid down by the Executive Board. The projects are: Seminar (since 1973), Journal and Library (since 1973), Language Instruction (since 1973), Industrial Instrumentation (since 1977), Industrial Technology Support (since 1978), Energy Conservation (since 1981), and Quality Control (QC) (since 1982). All projects set up after 1973 were actually offshoots of the Seminar projects.

Figures 1, 2, and 3 summarize past activities of TPA (1973 to 1983) in terms of number of courses, number of participants, and operating budget, respectively. It is noteworthy that the reputation of TPA as a private non-profit center for technological promotion and transfer has grown hand in hand with its activities, which see participants from nationwide.

\section{TPA and Powder Technology}

So far TPA has not given adequate attention to powder technology, partly because it judges that powder techno-

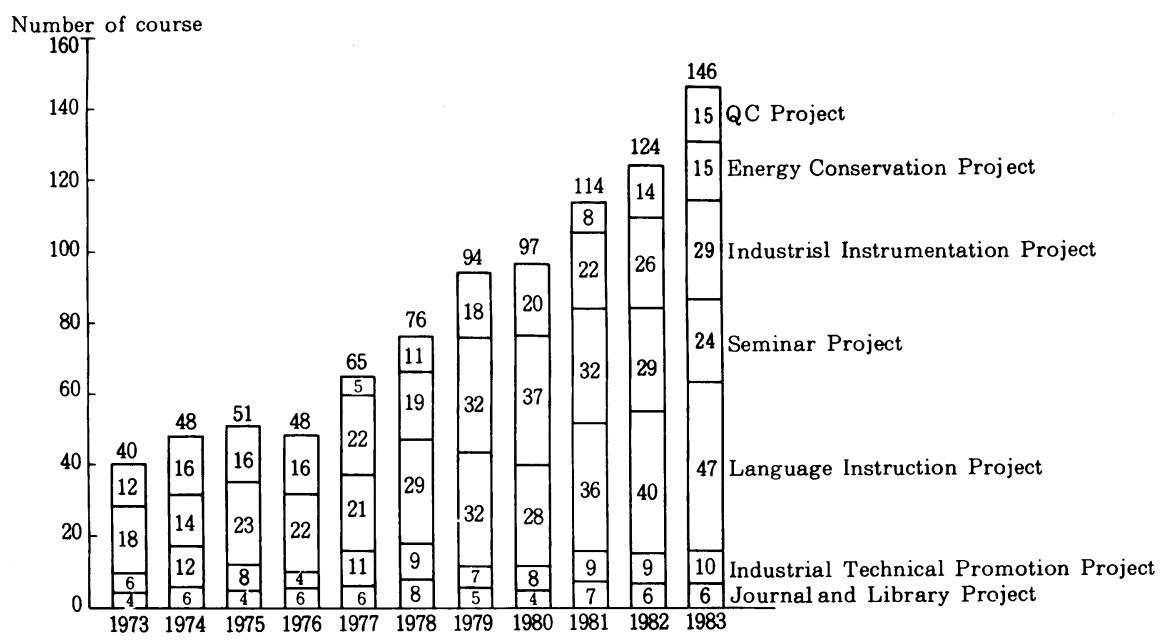

Fig. 1 Growth in TPA activities from 1973 to 1983

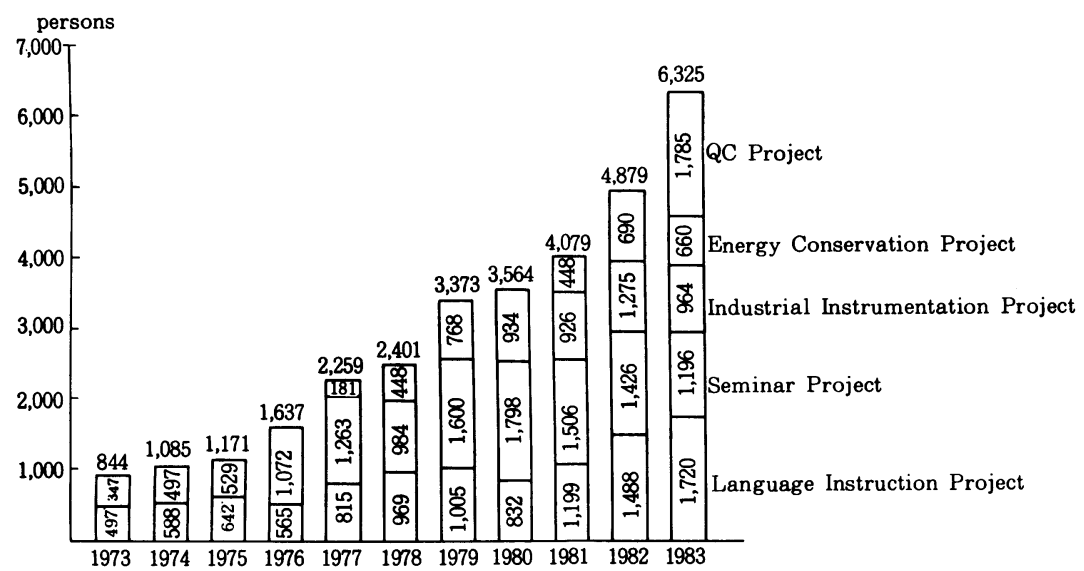

Fig. 2 Participants in activitives organised by TPA from 1973 to 1983 


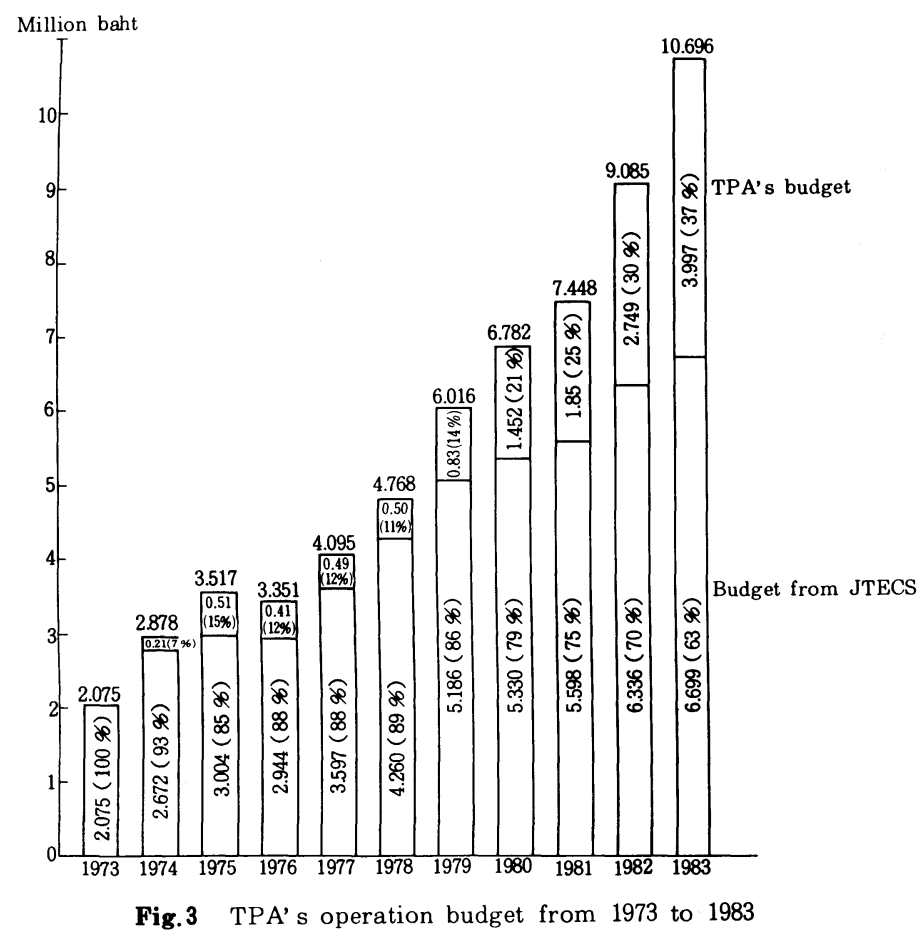

logy as a tool is not new to Thailand, whereas powder technology as a discipline is too specialized for the present need of Thai industries. In fact it was not until 1979 that such common chemical engineering operations as heat transfer and drying first received promotion from TPA. In relation to powder technology, the first closely indentifiable seminar was on Air Pollution: Measurement \& Control, which included dust collection equipment. Recently, the author has suggested such seminars as bulk solids handling, and pneumatic conveying, all to no avail. Party TPA is afraid that such seminars may dwell too heavily on the design and theoretical aspects, of which Thai industries have little need. Partly it does not know any foreign experts who can give them good advice on the

Through the Industrial Technology Support project currently publishes eight new titles as well as reprints many more annually, the only text closely related to powder technology is again Air Pollution: General Knowledge, Measurement, and Control. Nevertheless, a plan is already a foot to translate and publish a small Japanese handbook that contains several aspects of powder technology, such as pneumatic conveying, dust collection, and size classification. Though this is an encouraging sign, it will require much more effort to convince TPA of the full potential of powder technology in Thailand.

\section{When Will Powder Technology Make Its Pre- sence Felt in Thailand?}

The answer to this question is "It depends . . . ." It depends on how rapidly the industrialization of Thailand will proceed, how much alternate energy resources, such as coal and lignite Thailand plans to substitute for oil, how quickly the food processing industry will grow, how strict the government's emission standards will become, and a host of other foreseeable and unforeseeable factors, both technical contents and whom to invite as lecturers. internal and external.

To the author, however, the most urgent problem remains how to organize a core group of academicians and industrial practitioners with keen interest in powder technology. Such a group is a prerequisite for powder technology to take root and flourish in Thailand. This may sound quite simple to some, but the author does not believe so. What is urgently called for is the introduction of powder technology as a discipline, along with a few convincing demonstrations of its usefulness, via the holding of seminars, workshops, intensive courses and so on. In this regard, Chulalongkorn University, the leader in engineering, as well as the Engineering Institute of Thailand and TPA, is in an excellent position to help, especially if foreign cooperation in the form of sound advice and useful expertise be available. 